\title{
The Investigation and Analysis of the Humanistic Spirit of University P. E. Teachers
}

\author{
Xu Degang \\ Department of Physical Education of Zaozhuang University \\ Zaozhuang, Shandong Province, 277160 \\ xudegangwl@126.com
}

\begin{abstract}
Through the investigation and analysis of humanistic spirit of college physical education teachers, the present situation of humanistic spirit of college physical education teachers is displayed, which provides a theoretical basis for strengthening the humanistic spirit construction of physical education teachers in Colleges and universities. By using the method of questionnaire, literature data method, expert interview method, mathematical statistics method, the study found that university PE Teachers' ideals and beliefs, "the pursuit of utilitarian, light training, practical" has become part of the physical education teachers choose the value standard of knowledge, value orientation of utilitarian tendency, to improve the moral standards. It puts forward that the humanistic quality of college physical education teachers should be improved, such as perfecting the system, strengthening the reserve of humanistic knowledge, accumulating the humanistic spirit and establishing the modern educational concept. This paper uses the form of data to reveal the current situation of humanistic spirit of physical education teachers in Colleges and universities, and has certain theoretical value.
\end{abstract}

Keywords-university $P . \quad$ E. teachers; humanistic quality; humanistic spirit; investigation and analysis

\section{INTRODUCTION}

It is very important for humanistic spirit of university $\mathrm{P}$. E. teachers to build mind and the significance of ideological education. Through the culture edifying of sports and humanities, university students can grasp the essence of sports in practice and experience the meaning of sports to their cultivation and care [1]. Therefore, in accepting the education of sports, we should carry out the humanistic spirit into daily study and life so as to ensure the soundness and development of ourselves and society. In terms of the overall level of university P. E. teachers, the professional basic theory is more solid, the sports skill and the sports special level are higher. But the common problems are that the knowledge structure is unitary and lack humanistic knowledge. It cannot be internalized good humanistic spirit and leads to low humanistic spirit of university P. E. teacher. On the day of the qualityoriented education, it is more important to put the humanistic spirit of university P. E. teachers in an important position so as to improve the real role of P. E. education in education system[2].

\section{RESEARCH OBJECTS AND CONTENTS}

\section{A. Research Subjects}

Twenty colleges and universities in- service university P. E. teacher of five provinces and one municipality, Shandong, jiangsu, an' hui, Hubei, Qinghai, and Tianjin.

\section{B. Research Contents}

From the investigation and analysis of the humanistic spirit of university P. E. teachers, we put forward the basic countermeasures and suggestions systematically for improving the humanistic spirit of university P. E. teachers.

\section{Research Methods}

\section{1) Questionnaire method}

The questionnaire distribution and recycling time are from September 2016 to December 2016. 400 questionnaires were sent out, 336 recovered, $84.0 \%$ recovery rate, 290 effective questionnaires, $86.3 \%$ effective, including 208 males and 82 females.

\section{2) Literature method}

Through the Chinese journal network (CNKI), this paper reviewed the database of the full-text database of master degree of Chinese excellent blogs in China in the past 10 years, and the retrieval of the full-text database of Chinese important conference proceedings. It has reviewed more than 100 literatures related to domestic and foreign countries, and has written more than 20 works.

\section{3) Expert interview method}

We visit university sports experts and professors to collects information and materials about humanistic spirit of university P. E. teachers.

\section{4) Mathematical statistics method}

The data and information of the collected questionnaires and interviews were established on the computer, using Excel statistics and analysis. 
III. RESULTS AND ANALYSIS
A. The ideals and beliefs of some university P. E. teachers are not strong enough

TABLE I. IDEALS AND BELIEFS STATUS OF UNIVERSITY P. E. TEACHERS

\begin{tabular}{|c|c|c|c|c|}
\hline $\begin{array}{c}\text { sequence } \\
\text { Numbers }\end{array}$ & propositions & yes & not to matter & no \\
\hline one & $\begin{array}{c}\text { there is a sense of holy feeling and pride in } \\
\text { participating in the flag raising ceremony }\end{array}$ & $83.4 \%$ & $16.6 \%$ & 0 \\
\hline two & $\begin{array}{c}\text { are you interested in the long-term future of this } \\
\text { major }\end{array}$ & $78.6 \%$ & $19.7 \%$ & $1.7 \%$ \\
\hline
\end{tabular}

In the questionnaire, 83.4 percent of the participants felt a sense of holy feeling, a sense of pride, and 16.6 percent of the participants felt a sense of formalism. 78.6 percent of the participants expressed concern about the long-term future of this major, 19.7 percent of the participants didn't matter, and 1.7 percent of the participants aren't paying attention. The questionnaire shows that most P. E. teachers can deeply study their subjects and focus on the frontier areas of the discipline.

TABLE II. INFORMATION ON THE IDEALS AND BELIEFS STATUS OF UNIVERSITY P. E. TEACHERS

\begin{tabular}{|c|c|c|c|c|c|c|c|c|}
\hline propositions & options & $\begin{array}{c}\text { ratio } \\
\%\end{array}$ & options & $\begin{array}{c}\text { ratio } \\
\%\end{array}$ & options & $\begin{array}{c}\text { ratio } \\
\%\end{array}$ & options & $\begin{array}{c}\text { ratio } \\
\%\end{array}$ \\
\hline $\begin{array}{c}1 \text { the primary } \\
\text { purpose of } \\
\text { learning } \\
\text { knowledge }\end{array}$ & $\begin{array}{c}\text { to calculate the } \\
\text { utility }\end{array}$ & 9.0 & pragmatic & 44.8 & earn money & 8.9 & $\begin{array}{c}\text { achieve } \\
\text { the ideals }\end{array}$ & 37.1 \\
\hline 2 social evils & $\begin{array}{c}\text { hatred is } \\
\text { powerless to } \\
\text { stop }\end{array}$ & 75.5 & restrain & 7.2 & $\begin{array}{c}\text { associate with } \\
\text { an evil persons }\end{array}$ & 2.4 & try to stop & 14.9 \\
\hline $\begin{array}{c}3 \text { the things } \\
\text { that matter } \\
\text { most }\end{array}$ & $\begin{array}{c}\text { anti-corruption } \\
\text { bid }\end{array}$ & 62.0 & workers & 24.8 & $\begin{array}{c}\text { congress of } \\
\text { party } \\
\text { representatives }\end{array}$ & 12.1 & $\begin{array}{c}\text { tax } \\
\text { evasion }\end{array}$ & 1.1 \\
\hline $\begin{array}{c}4 \text { the most } \\
\text { likely cause } \\
\text { of your } \\
\text { indignation }\end{array}$ & $\begin{array}{c}\text { national } \\
\text { humiliation }\end{array}$ & 45.9 & $\begin{array}{l}\text { Tpersonal } \\
\text { dignity }\end{array}$ & 30.0 & $\begin{array}{c}\text { harm the } \\
\text { environment }\end{array}$ & 5.9 & corruption & 18.2 \\
\hline
\end{tabular}

9.0 percent of the participants believe that the primary purpose of learning knowledge is to seek utility, 44.8 percent of the participants think pragmatically, only 8.9 percent of the participants to make money, and 37.1 percent of the participants believe that the primary purpose of learning knowledge is to achieve the ideals. When we enter a period of market-oriented economy, people show the pursuit of economic interests. Social work and life show an obvious utilitarian tendency to focus on the practical and strong subjects, while neglecting the basic humanities. "The pursuit of utilitarianism, self-cultivation, practical first" has become the value standard for some university P. E. teachers to choose their knowledge. They tend to pay too much attention to the cultivation of employability, but neglect the cultivation of the responsibility consciousness and the cultivation of emotional factors, which leads to the lack of humanistic spirit.

"The most likely cause of your indignation" survey accounted for $45.9 \%$ of national humiliation, personal dignity trampled accounted for $30.0 \%, 5.9 \%$ think is environmental protection, $18.2 \%$ believe that corruption is the most likely cause of your indignation. Influenced by traditional culture, Chinese have always regard the concept "self-cultivation, family harmony, country management and world peace" as their own life ideal and life attitude, formed the Chinese characteristic human genes with emphasizing national cohesion, national pride and national first. Therefore, in contemporary higher education of China. We must associate the human genes with positive life ideal and value concept. The spirit of humanity has experienced vicissitudes, which can be handed down from generation to generation. The personal dignity of the questionnaire was trampled at $30.0 \%$, and we thought about it [3].

In $75.5 \%$ of the questionnaire for the society all sorts of despicable behavior is hated and unable to stop, and 7.2\% don't want to stop, colluding with $2.4 \%$ of people think, with $14.9 \%$ of people trying to stop the society all sorts of despicable behavior. The above data indicate our part of the university $\mathrm{P}$. E. teachers should strengthen human construction greatly, "integrate" and establish one's own school of thought, which 
forms the unique understanding of society, feeling, ideas and beliefs for life and history.

The top concern is $62.0 \%$ of the anti-corruption advocates, $24.8 \%$ of those who pay attention to the reemployment of laidoff workers, and $12.1 \%$ of the party congress and the people's congress, and 1.1 percent concerned about tax evasion. $62.5 \%$ of the questionnaires said that the greatest happiness of human being was useful to others, to the society, 1.7 percent to occupy, 34.8 percent to enjoy life, and 0.7 percent thought that the greatest happiness of being a man was to be prominent. The data show that P. E. teachers can put personal development and future linked with the development and the future of the country, put himself to the motherland the deep emotion, and hope for national rejuvenation into the love of sports education career and to student's love and tolerance. I will always keep my passion for the education career and devote my intelligence and wisdom to the people's education career. I will strive to become a caring and respected teacher.

B. The personality and moral standards of some university $P$. E. teachers need to be improved

TABLE III. PERSONALITY AND MORAL STATUS OF UNIVERSITY P. E. TEACHERS

\begin{tabular}{|c|c|c|c|c|}
\hline $\begin{array}{c}\text { sequence } \\
\text { numbers }\end{array}$ & propositions & yes & $\begin{array}{c}\text { hard to } \\
\text { explain or not } \\
\text { to matter }\end{array}$ & no \\
\hline 1 & $\begin{array}{c}\text { when you are in trouble, you can always be solved by the } \\
\text { help of the group }\end{array}$ & $25.5 \%$ & $59.3 \%$ & $15.2 \%$ \\
\hline 2 & $\begin{array}{c}\text { the individual interests are not satisfied, social dedication } \\
\text { is a wonderful lie }\end{array}$ & $31.4 \%$ & $36.9 \%$ & $31.7 \%$ \\
\hline 3 & Are you complying with the traffic safety law? & $34.8 \%$ & $63.5 \%$ & $1.7 \%$ \\
\hline 4 & $\begin{array}{c}\text { in the course of teaching, whether you pay attention to } \\
\text { the students' humanistic quality training }\end{array}$ & $38.6 \%$ & $60.4 \%$ & $1.0 \%$ \\
\hline 5 & we are in favor of poverty alleviation and disability \\
activities & $83.5 \%$ & $15.5 \%$ & $1.0 \%$ \\
\hline 6 & university P. E. teachers are more professional & $36.6 \%$ & $58.6 \%$ & $4.8 \%$ \\
\hline 7 & you are emotionally accepting a tax on bank savings & $24.2 \%$ & $37.9 \%$ & $37.9 \%$ \\
\hline
\end{tabular}

Having difficulty with a questionnaire, $25.5 \%$ of people can always through collective help to solve, not through collective $15.2 \%, 59.3 \%$ of people have, that focus on self and others to the survival and development of the mutual dependence is not enough.

In the questionnaire, $31.4 \%$ of people were dissatisfied with their personal interests, and the social contribution was just a wonderful lie, which was agreed to. $36.9 \%$ were not clear, and $31.7 \%$ disagreed. The data show that some of university P. E. teachers lack humanistic spirit, which mainly show the distortion of the life value, the value of money and the extreme personalization, and emphasis of individual struggle, poor team spirit, and utilitarian tendency obvious, etc. The current education neglect or lack emphasis on the cultivation of humanistic spirit in market economy conditions, which is the direct cause and the main reason.

There are 34.8 percent of the people who strictly abide by the traffic safety law, and 1.7 percent of those who do not comply, and 63.5 percent of those who do not comply. $38.6 \%$ were very concerned about the humanistic quality of students, $60.4 \%$ of them were concerned about this occasionally, and $1.0 \%$ didn't pay attention to it. Some P. E. teachers lack responsibility for students, lack communication with students and have no feelings for students. They just meet in class and don't care about the overall development of students. Although these phenomena are only in the minority, the mainstream of the teacher is good. We should see that these problems are quite serious, and it is incompatible with the mission of the teachers. In fact, this situation has had a lot of negative impact on the development of education.
There are $83.5 \%$ of those who approve of poverty alleviation and disability activities, and $15.5 \%$ are indifferent to this, only $1.0 \%$ disapprove. In the survey of university P. E. teachers' professionalism, $36.6 \%$ were satisfied, while $58.6 \%$ were not satisfied with the average of $4.8 \%$. $24.2 \%$ of people were emotionally absorbed by bank savings, $37.9 \%$ said they did not, and $37.9 \%$ said they did not.

In questionnaire, 72.1 percent of the people think that if you want to succeed, you need to rely on. $2.1 \%$ think that want to rely on others to help, with $11.0 \%$ considered by family background, $14.8 \%$ think that if you want to succeed, you need to rely on opportunity. In the questionnaire, there were $67.9 \%$ of the attitudes towards environmental protection in life, while the action was environmentally friendly, and 0.7 percent disapproved, with a $31.4 \%$ approval and a lack of attention. In nature, it is important to understand the position of human beings in nature, view the environment as the foundation of life and existence, and to be responsible for the future and sustainable development. But there are still $32.1 \%$ of teachers who don't pay attention to the environment. These show that part of the P. E. teachers can not correctly understand and deal with people and nature, man and society, and the basic relationship between people and people. They couldn't figure it out for teacher's lofty responsibility, thus they not clear the value and significance of life and perfunctory for job. It naturally affects the education quality and effect [4]. It also shows the tendency of value orientation, personality and moral standards need to be improved. 


\section{COUNTERMEASURES AND SUGGESTIONS}

\section{A. Increase the proportion of the humanities education on the curriculum setting}

Physical education specialty, sports training, national traditional sports professional major courses are more technical and craft courses. The teaching goals more determined in the technical level, performance and results. In the course of the curriculum, the content of the humanistic knowledge is less considered, and the course of teaching and learning is lack of education in the humanities. It leads to lack humanistic spirit of university P. E. teachers.

\section{B. Leadership recognition}

The party committee of colleges and universities should include the education work of the teacher humanistic spirit in the overall plan of school teachers' ideological and political work, and formulate the methods and measures for the humanistic spirit education suited to the characteristics of colleges and universities. School leaders play a key role in advancing the construction of humanistic spirit of teachers. As school spirit and centralized authority, the leader's emphasis on the humanities and concerns itself is a kind of an underlying strength, suggesting a signal, and showing the tendency of school behavior.

\section{Sound system}

To improve the humanistic spirit of P. E. teachers, it relies on education and system. Without perfect and scientific management system, it is also difficult to improve the humanistic spirit of P. E. teachers. With the further development of institutions and personnel system reform, teachers implement the implementation of teacher's post, teacher engagement system, teachers' promotion system and teachers' performance appraisal system, which realizes the specialization of teaching occupation. In addition to introducing, selecting, cultivating, using, rewarding and other aspects of high-quality talents, we should reform the existing personnel system of teachers in colleges and universities. Through the reform of personnel system, it arouses enthusiasm, initiative and creativity of the teachers and carry forward the humanistic spirit of teachers. Therefore, the establishment of a relatively perfect teacher management system is conducive to the spirit of dedication of the teachers, and last this spirit and form a virtuous circle.

\section{Strengthen the cultural knowledge reserve and improve the transformation of the humanistic spirit}

Improvement of humanistic spirit of university P. E. teachers not only embodies the accumulation of cultural knowledge of P. E. teachers, but also embodies understanding of humanities knowledge level and the extent of the transformation of the humanistic spirit. Finally, it manifests the shape on the outlook on life, world and values. Humanistic spirit is the core content of teachers' humanistic quality. P. E. teachers only accumulate humanistic knowledge and does not understand and transform humanities knowledge, they won't form the humanistic spirit of the individual and won't translate into teacher's outlook on life, world and values. They also won't form humanistic human behavior of teachers.

\section{E. Build a good humanistic spirit}

The humanistic spirit of P. E. teachers is embodied in all aspects. Such as, subjective spirit that is not served by anyone, the spirit of dedication to the job and education, spirits on seeking truth from facts and innovative spirit aimed at the allround development of people and society, etc. We should increase the propaganda of noble humanistic spirit, form a right public opinion direction in the general teachers, form a kind of indifferent to fame and wealth and advocate the humanistic spirit atmosphere of my career [5]. Teachers gain new feelings and understanding to oneself, to others, to the environment and internalize inner character on basis of certain humanities knowledge and physical teaching activity and the participation, observation and reflection of the situation. In the process of understanding, it obtains a noble humanistic spirit

\section{F. Work hard to create personality charm of P. E. teachers}

Personality charm is the embodiment of cultural literacy in the behavior and manner of P. E. teachers. A knowledgeable, experienced and tasteful teacher influences his students from his personality charms. P. E. teacher's personality charm can directly impact on students wordlessly and perpetually. PE teachers' personality should be strong and handsome body, optimistic open-minded, tolerance and trust to the student. It makes students enjoy interacting with him. Students regard P. E. teachers as their model for their learning. The personality charm of P. E. teachers reflects the values of social culture, aesthetic emotion [6], etc., which is an important reference for students' individual culture construction. Therefore, it is helpful to improve the humanistic spirit of P. E. teachers, thus forming radiation and improving the humanistic spirit of education objects in education process.

While advocating science and rationality, people pay more attention to the return of humanity than ever before, and promote the realization of creative ability, innovative spirit and personal value. It is more necessary for university P. E. teachers to set up lofty ideals and noble moral sentiments, to unite other teachers, to give full play to the advantages of the group and to build a better future for university students.

\section{REFERENCES}

[1] Zhang Qizhi. Efforts should be made to improve the humanistic quality of university teachers [J]. China's higher education, 2000: 4.

[2] Ji Liu, Hu Zengluo. Physical education outlook [M]. Shanghai: East China Normal University press, 2001: 99.

[3] Zhu Pengping. Current situation and Countermeasures of humanistic quality of college physical education teachers [J]. Journal of Capital Institute of Physical Education, December 2001: 51 53.

[4] Li. The foreign Ngoc Huong humanistic education in Colleges and universities and the Enlightenment of the "return" of $[\mathrm{J}]$. Higher education, 1997: 6.

[5] Hu Xiang Feng. Teacher Education Research on [J]. 2000: 9.

[6] Qin Hongbin. Eight paths to strengthen humanistic quality education in Colleges and universities [J]. Modern education, June 2006: 64 66. 